\title{
25. Sudûr nazariyesinin gelişimi ve Abdülhak Hâmid Tarhan'ın şiirle Sudûr nazariyesine kazandırdığı yeni bir boyut
}

Ömer Faruk KARATAŞ ${ }^{1}$

\begin{abstract}
APA: Karataş, Ö. F. (2021). Sudûr nazariyesinin gelişimi ve Abdülhak Hâmid Tarhan'ın şiirle Sudûr nazariyesine kazandırdığı yeni bir boyut. RumeliDE Dil ve Edebiyat Araştırmaları Dergisi, (22), 423-436. DOI: $10.29000 /$ rumelide.886148.
\end{abstract}

\section{$\ddot{O} \mathbf{z}$}

Bütün unsurlarıyla evrenin nasıl meydana geldiğinin merak edilmesi ve bu merakla çeşitli teoriler üretilmesi, insanlık tarihiyle yaşıt mevzulardandır. Yaratılış teorileri arasındaki yerini Helenistik dönemde alan Sudûr nazariyesi, Yeni Platoncu akımın kurucusu Plotinos'un geliştirdiği bir teoridir. Plotinos'a göre evren, varlığa kaynaklık eden Tanrı'dan Nous (Zekâ)'un taşması ve aşağıya doğru gitgide somutlaşarak çeşitli katmanlar meydana getirmesiyle meydana gelir. Plotinus tarafından ortaya atılan bu teori, Orta Çă̆ İslam filozofları tarafından benimsenir ve Sudûr nazariyesi İslam felsefesine taşınır. Bu aşamada bazı değişikliklere uğratılmasına rağmen Sudûr nazariyesi, Fârâbî ve İbn Sînâ'nın düşünce sistemlerinde Plotinos'un ileri sürdüğü gibi, Tanrı'dan Akıl’nn taşması boyutuyla kendini gösterir. Ancak Sühreverdî, kendi kozmogonik düşüncelerini oluştururken yararlandığı Sudûr nazariyesinde, Tanrı'dan taşan unsurun Akıl değil, Nûr olduğunu ileri sürerek, teoriye yeni bir boyut kazandırır. Tanrı'dan taşan Nûr düşüncesi, bilhassa Vahdet-i Vücûd öğretisiyle tasavvuf tarihine damgasını vurmuş İbn Arabî’nin düşüncelerine tesir eder. Tasavvuf sistemi üzerinden Divan şiirine de yansıyan Sudûr nazariyesi, klasik şiirin vazgeçilmez yaratılış teorisi olarak, asırlar boyunca Türk şiirinde varlığını sürdürür. Böylelikle Tanzimat’la birlikte yönünü Batı'ya çevirip yeni bir kimliğe bürünen Türk şiirinde de geleneksel bir yaklaşım olarak kendine yer edinmeyi başarır. Hatta Tanzimat şairlerinden Abdülhak Hâmid Tarhan, Sudûr nazariyesini şiirlerine taşırken, Tanrı'dan taşan unsurun Akıl veya Nûr değil, Zaman olduğunu iddia ederek, nazariyeyi bambaşka bir boyuta taşır.

Anahtar kelimeler: Abdülhak Hâmid Tarhan, Batı felsefesi, İslam felsefesi, Sudûr nazariyesi, tasavvuf

\section{The development of the theory of Sudûr and a new dimension given to it by Abdülhak Hâmid Tarhan through poetry}

\begin{abstract}
Wondering how the universe with all its elements came into being and producing various theories with this curiosity are issues that are as old as human history. The theory of Sudûr, which took its place among the creation theories in the Hellenistic period, is a theory developed by Plotinos, the founder of the Neo-Platonic movement. According to Plotinos, the universe is formed by the overflow of Nous (Intelligence) from God, which is the source of existence, and formed by gradual downward concretizing and forming various layers. This theory, put forward by Plotinus, was adopted by medieval Islamic philosophers and the theory of Sudûr was transferred to Islamic philosophy. Although it has undergone some changes at this stage, the theory of Sudûr shows itself

Arș. Gör., Atatürk Üniversitesi, Edebiyat Fakültesi, Türk Dili ve Edebiyatı Bölümü (Erzurum, Türkiye), faruk.karatas@atauni.edu.tr, ORCID ID: 00oo-0001-5668-9749 [Araştırma makalesi, Makale kayit tarihi: 28.11.2020kabul tarihi: 20.03.2021; DOI: 10.2900o/rumelide.886148

Adres $\mid$ Address

RumeliDE Dil ve Edebiyat Araşttrmaları Dergisi $\quad$ RumeliDE Journal of Language and Literature Studies Osmanağa Mahallesi, Mürver Çiçeği Sokak, No:14/8 Osmanağa Mahallesi, Mürver Çiçeği Sokak, No:14/8

Kadıköy - İSTANBUL / TÜRKIYE 34714 Kadıköy - ISTANBUL / TURKEY 34714 e-posta: editor@rumelide.com

e-mail: editor@rumelide.com

tel: +90 505 7958124, +90 216773 o 616 phone: +90 505 7958124, +90 2167730616
\end{abstract}


The development of the theory of Sudûr and a new dimension given to it by Abdülhak Hâmid Tarhan through poetry / Ö. F. Karataş (pp. 423-436)

\begin{abstract}
in the thought systems of Fârâbî and Ibn Sînâ, as Plotinos argued, with the overflow of Reason from God. However, Sühreverdî adds a new dimension to the theory by asserting that the element overflowing from God is not Reason, but Nûr, in the theory of Sudûr, which he uses while creating his own cosmogonic thoughts. The thought of Nûr overflowing from God influences the thoughts of Ibn Arabî, who left his mark on the history of sufism, especially with the doctrine of Vahdat-i Wujud. The theory of Sudûr, which is also reflected in Divan poetry through the sufism system, continues its existence in Turkish poetry for centuries as the indispensable creation theory of classical poetry. Thus, with the Tanzimat, it manages to take a place as a traditional approach in Turkish poetry, which turns its direction towards the West and assumes a new identity. In fact, Abdülhak Hâmid Tarhan, one of the Tanzimat poets, carries the theory of Sudûr to his poems, claiming that the element overflowing from God is not Reason or Light, but Time, and he takes theology to a completely different dimension.
\end{abstract}

Keywords: Abdülhak Hâmid Tarhan, Islamic philosophy, Sufism, the theory of Sudûr, Western philosophy

\title{
Giriş
}

Kelime anlamı itibarıyla "doğmak, meydana çıkmak, sâdır olmak, zuhur etmek" (Kaya, 2009: 467) anlamına gelen sudûr (emanation-feyz-türüm) kelimesi, felsefî bir terim olarak ise, "bütün türemiş veya ikincil şeylerin temel ya da ilksel olan bir şeyden çlkmalar, varhğa gelmeleri işlemi ya da süreci”ni (Cevizci, 2013: 1559) ifade eder. Bir yaratılış teorisi teşkil etmesi bakımından Sudûr nazariyesi, ezelî ve ebedî olarak var olması zorunlu olan ilksel varlık ile bu varlığın özünü teşkil eden unsurun kaynağından taşması sonucunda soyuttan somuta doğru çeşitli varlık katmanlarından müteşekkil varlık âleminin meydana gelmesine dayalı bir teoridir.

Sudûr nazariyesinde, varlığa kaynaklık edecek ilksel varlığın, zorunlu olarak ezelî ve ebedî şekilde var olması gerektiği gibi, kendi varlığını kendinden alması, değişmemesi, bölünmemesi, hatta aşkın ve yetkin olması da zaruridir. Mevzubahis nitelikleri bünyesinde toplayan yegâne varlığın sadece Tanrı olduğu düşünüldüğünden, Sudûr nazariyesinin ihtiyaç duyduğu ilksel varlığın da Tanrı'dan başka bir varlık olamayacağına kanaat getirilir (Hançerlioğlu, 2012: 402). Ayrıca nazariyenin en temel fonksiyonunu belirten taşma faaliyetinin de zorunluluğa bağlanması sonucunda, evrenin meydana geliş süreci boyunca Tanrı'nın herhangi bir eylemde bulunmadı̆̆ı yargısına ulaşılır (Zeller, 2008: 390).

Yaratmanın bir eylem olduğu gerçeğinden hareket edildiğinde ve her eylemin de bir değişmeyi beraberinde getirdiği düşünüldüğünde, Sudûr nazariyesiyle kâinatın meydana gelebilmesi için Tanrı'nın herhangi bir eylemde bulunmak zorunda kalmayacağı bir teori geliştirilmiş olur. Böylelikle Tanrı'nın doğrudan kâinatı yarattığına dair görüşün gündeme getirdiği, eylem gerçekleştiren Tanrı tasarımıyla zedelendiği düşünülen Tanrı'nın değişmezliği, saflığı, birliği, edimselliği ve yetkinliği gibi hususlar mutlak düzeye ulaştırılır veya bu niteliklere düşen gölge bertaraf edilmiş olur (Cevizci, 2011: 163-164).

Tarihsel süreç bakımından, ilk olarak Helenistik dönem filozoflarından Plotinos’un felsefe dünyasına kazandırdığı Sudûr nazariyesi, Batı felsefesinde ortaya çıkmakla kalmayıp, Orta Çă̆ Hıristiyan ve İslam felsefesini derinden etkilemiş bir teoridir. İslam filozofları tarafından makul karşılanarak, bazı değişikliklerle İslam felsefesine taşınan Sudûr nazariyesi, böylelikle değişip gelişerek tasavvuf düşüncesinin de merkezine yerleşir (Ülken, 2014: 121). Tasavvuf sistemiyle yakından ilişkili olan Divan

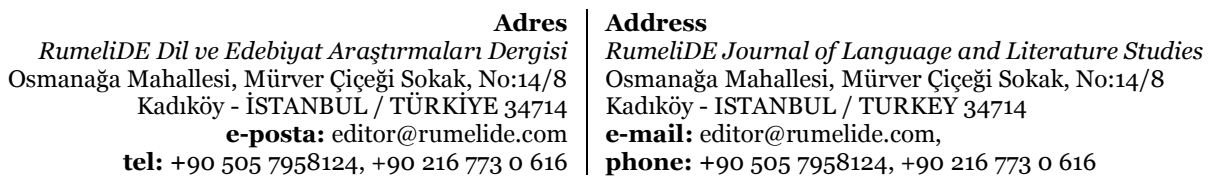


şiirine de yansıyan ve tasavvuf üzerinden klasik şiirin en temel yapı taşlarından biri hâline gelen Sudûr nazariyesi, elbette Tanzimat dönemiyle birlikte yapı ve tema bakımından değişmeye çalışan, fakat bir anda topyekûn kabuk değiştirmesi elbette mümkün olmayan yeni Türk şiirinde de varlığını devam ettirir. Hatta Tanzimat şairlerinin önde gelen isimlerinden Abdülhak Hamid Tarhan, Sudûr nazariyesine yeni ve oldukça farklı bir boyut kazandırır.

\section{Batı felsefesinde Sudûr nazariyesi}

Plotinos tarafından felsefe dünyasına sunulan Yeni Platonculuk akımı, Helenistik dönemin son önemli felsefe ekolü olarak ön plana çıkar. Adından da anlaşıldığı üzere, Platon'un idealar âlemi ve fenomenler âlemine dayalı birbirinden ayrı iki âlem anlayışının yeniden yorumlanması olarak görülen Yeni Platonculuk anlayışı, Plotinos'un Platon'dan devraldı̆̆ "iyi” ideasını tanrılaştırmak suretiyle, felsefe sistemine mistik tecrübeyi dâhil etmesi sonucunda meydana gelir (Weber, 1998: 112). Bu bakımdan Plotinos, Materyalist bir felsefe geliştirmektense, Tanrı fikrine yönelmeyi tercih ederek, felsefi düşüncelerini âdeta bir inanç sistemi kimliğine büründürür (Gökberk, 2013: 118). Dolayısıyla felsefi düşüncelerini dinle eklemlendirmeye çalışan Orta Çă̆ filozoflarını derinden etkileyen Plotinos'un fikirleri, İlk Çă̆ felsefesi ile Orta Çağ felsefesi arasında kurulmuş bir köprü olarak nitelendirilir.

Plotinos'un Sudûr nazariyesi adıyla tanınan yaratılış teorisi, "Bir" olandan hiyerarşik düzen dâhilinde gerçekleşen taşma faaliyetini ifade eder. Plotinos açısından, durmaksızın değişen ve çokluk sergileyen maddi dünya gerçeklikten uzaktır. Çünkü mutlak hakikat, değişmeyeceği gibi, çokluktan da kaçınmak, diğer bir ifadeyle birlik sergilemek zorundadır. Bu doğrultuda Plotinos'un mutlak hakikat diye değerlendirdiği "Birlik", asıl itibarıyla Tanrı'yı belirtir. Bir olan, sözcüklerle ifade edilemeyecek derecede aşkın bir değerdir. Çünkü akıl yordamıyla kavranamayan Tanrı, dil aracılı̆̆ıyla da ifade edilemez niteliktedir. Tanrı'yı tasvir edebilmek amacıyla beyan edilen her söz, sadece Tanrı'yı sinırlandırmaktan başka bir işe yaramayacaktır (Plotinos, 2008: 112-113). Ezelî ve ebedî olan Tanrı, bütün varlıkların mutlak kaynağını teşkil eder. Bu bakımdan kendinden türemiş varlıklarda algılanabilen bütün niteliklerden uzak yapıdaki Tanrı; sonsuz, varlığa gelmediği için asla yok da olmayacak, kendinden başka hiçbir şeye gereksinim duymayan, değişmediği için her zaman kendiyle aynı kalan, bölünmez ve saf "Birlik”ten ibarettir.

Bir, Zekâ'nın üzerindedir; o, tüm varlıkların kusursuz biçimde basit (sade) olan ilkesidir; onları bizzat kendi kendinde kalarak meydana getirmektedir ve bilhassa da onlar vasitasiyla tanınmaktadır. O, bizzat kendinde, kudreti vasitasıyla bölünmezdir ve sonsuzdur. Diğer varlıkların sebebi olması nedeniyle ne mevcut olmak için, tüm şeyler onun üzerine kurulmuş olduğundan dolayı ne bir temele sahip olmak için, hiçbir şeye can atmadığından dolayı da ne mutlu olmak için hiçbir şeye ihtiyaç duymadı̆̆ından ve aşkın bir tarzda İyi olduğundan dolayı, o mutlaktır. (Plotinos, 2008: 175)

Tanrı'nın evreni nasıl meydana getirdiği mevzuunda ise, Sudûr nazariyesini ortaya atan Plotinos, Tanrı’nın evreni yoktan var etmediği gibi, ezelî olarak var olan şekilsiz madde yığınını da belli bir düzene kavuşturmak suretiyle kâinatı yaratmadığı kanaatindedir. Platon'un düşüncelerinden yola çıkan Plotinos'a göre fenomenler âlemi, Tanrı'dan taşarak mevcudiyet kazanmıştır. Fakat Bir olandan veya Tanrı'dan belli bir hiyerarşik düzen içerisinde gerçekleşen taşma faaliyeti sayesinde ortaya çıkan fenomenler âlemi şekillenirken, Tanrı'nın özünde herhangi bir değişme veya hareket meydana gelmemiştir. Aynı doğrultuda fenomenler âleminin varlı̆̆a geliş süreci boyunca, asli cevher olarak Tanrı'nın bünyesinde herhangi bir bölünme veya eksilmeden de söz edilemez.

\footnotetext{
RumeliDE Dil ve Edebiyat Araşttrmaları Dergisi Osmanağa Mahallesi, Mürver Ciçeği Sokak, No:14/8 Kadıköy - İSTANBUL / TÜRKIYE 34714 e-posta: editor@rumelide.com tel: +90 505 7958124, +90 2167730616 
The development of the theory of Sudûr and a new dimension given to it by Abdülhak Hâmid Tarhan through poetry / Ö. F. Karataş (pp. 423-436)

Sudûr nazariyesinin üzerinde durduğu taşma faaliyeti, tıpkı Güneş’in etrafına ışık yayması veya saçması gibi gerçekleşir. Mevzubahis benzetmedeki Güneş, tek olan Tanrı'yı simgeler. Güneş’ten taşan ışınlar, Güneş’in yapısında herhangi bir azalmaya neden olmaz. Ayrıca bir tek ışının Güneş'e denk olduğunu kabul edebilmek de mantık açısından mümkün değildir. Bu bakımdan Tanrı'dan taşan unsurların Tanrı'ya denk olduğunu düşünmemek gerekir. Buna ilaveten yayılan ışınlar nasıl ki, Güneş'e en yakın oldukları konumda kuvvetli hâlde bulunup, Güneş’ten uzaklaştıkça zayıflayarak karanlığa gömülüyorlarsa, Tanrı'dan gerçekleşen taşmada esnasında da ışınların karanlığa daldığı nokta fenomenler âlemini ifade etmektedir (Jones, 2006: 26). Elbette fenomenler âlemine gelinceye kadar, bir başka deyişle ışınların kaynaktan karanlığa doğru seyrini belirten hat üzerinde, çeşitli katmanların meydana gelmesi gayet olağandır.

Plotinos'un ileri sürdüğü Sudûr nazariyesine göre, kendine egemen ve kusursuz hâldeki "Bir"den öncelikle Nous (Zekâ) sudûr eder. Nous, Tanrı'daki birliğin yerini çokluğa bırakacağı sürecin ilk aşamasını teşkil eder (Weber, 1998: 113-115). Sürecin devamında, "Bir"in sonsuz kudretini temaşa eden Nous'un bünyesinde "Bir"den yalnızca bir türer prensibi gereği, düşünen ile düşünülen nesne bir ve aynı olmak zorundadır. Sonraki aşamada Nous, kendini düşünmeye (kendinin bilincine varamaya) başlayınca, düşünen ile düşünülen ikiliği meydana gelerek, Nous'tan da Evrensel Ruh sudûr eder (Arslan, 2012: 92). Nous'u temaşa eden Evrensel Ruh, yeryüzünde olup biten her şeyi doğrudan veya dolaylı olarak düzene sokan unsurdur. Bu bakımdan Evrensel Ruh, soyut gerçeklikle somut gerçeklik arasında uzanan bir köprü görevi üstlenir. Sudûr nazariyesinin son aşamasını ifade eden Doğa ise, Evrensel Ruh'tan sudûr eder. Çünkü Evrensel Ruh'un bulunduğu konum gereği, Nous'a temas ettiği yönde, yani kendinden üstün gücün karşısında pasif, ancak şekil verme kabiliyetini kullanabildiği yönde, diğer bir ifadeyle kendinden aşağı kısma tesir ettiği noktada aktif olması gerekir. Bu nedenle biçimlendirmek üzere maddeye ihtiyaç duyması sonucu, kendinden sudûr eden Doğa'nın meydana gelmesi veya türemesiyle, türüm sürecinin başındaki birlik, yerini fenomenler âlemindeki çokluğa brrakır (Plotinos, 2008: 79-80).

Egemence kusursuz durumda olan Bir, kudretinin aşırı bolluğu vasıtasıyla Zekâ’yı meydana getirmiştir. Bir'e doğru olan yönelişi (ya da dönüşümü) vasıtasıyla bütünlüğüne (eksiksizliğine) ulaşan Zekâ da, kendi sırası geldiğinde Ruh'u oluşturmuştur. Ruh'un bizzat kendisi bütünlüğüne Zekầyı temaşa etmek suretiyle ulaşmıştır ve aynı şekilde o da meydana getirmiştir: böylece ondan da Doğa doğmuştur. (Plotinos, 2008: 110)

Kısacası Plotinos'un geliştirdiği Sudûr nazariyesine göre, yukarıdan aşağıya doğru sırasıyla, varlık âlemine kaynak teşkil eden "Bir”in bünyesinden Nous, Nous'tan Evrensel Ruh, Evrensel Ruh'tan da Doğa'nın sudûr etmesiyle soyuttan somuta doğru şekillenen topyekûn kâinat meydana gelir. Diğer bir ifadeyle Tanrı'dan taşan akıl, gitgide somutlaşarak bir bütün hâlinde varlık âlemini meydana getirir.

\section{2. İslam felsefesinde Sudûr nazariyesi}

İslam felsefesinde, yaratılmış veya mümkün varlıklar, sebep prensibi dâhilinde geriye doğru takip edildiğinde, diğer bir ifadeyle, hâlihazırda var olmayan bir varlığın varlığa gelebilmek için, kendinden önce varlık bulmuş bir başka varlığa ihtiyaç duyması göz önünde tutulduğunda, mümkün varlıkların tamamının müşterek bir sebebe ihtiyaç duyduğu anlaşılır. Herhangi bir mümkün varlıktan yola çıkılarak, sebep-sebepli zinciri geriye doğru götürüldüğünde, başlangıç noktasını teşkil edebilecek zorunlu bir varlığın gerekli olduğu fark edilir. Mevcut olmaması durumunda varlık âleminin meydana gelemeyeceği bu zorunlu ve ilk varlık, kendisi sebebe ihtiyaç duymaksızın varlığa sebep olan veya varlığa kaynak teşkil eden asıl varlıktır. Bu doğrultuda zorunlu varlık ve mümkün varlık ayrımına giderek, Tanrı'nın varlığını ve birliğini ispat etmekle kalmayan Fârâbî, aynı zamanda Sudûr 
nazariyesiyle açıklamaya çalışacağı kâinatın meydana geliş sürecindeki başlangıç noktasını da belirlemiş olur (Fârâbî, 2001: 15-19).

Fârâbî’nin ileri sürdüğü kozmogoniye göre, başlangıç itibarıyla Vâcibü’l Vücûd olarak Tanrı mevcuttur. Kâinatın meydana geliş süreci, ilk olarak Tanrı'nın kendi zâtını düşünmesi ve bilmesiyle başlar. Tanrı’nın kendi zâtını düşünmesi ve bilmesi üzerine, birden yalnızca bir çıkar prensibi gereği, Tanrı'dan kendi özünü idrak edebilme yetisine sahip İlk Akıl sudûr eder. İlk Akıl, Tanrı'ya nispetle zorunlu, kendi özü bakımından mümkün bir varlıktır. İlk Akıl da tıpkı Tanrı gibi düşünmeye başlar. Fakat Tanrı'dan farklı olarak, çoğalma potansiyeline sahip olduğundan, sadece kendinden türediği Tanrı’yı düşünmekle kalmaz, aynı zamanda mümkün bir varlık olarak kendi özünü de düşünür. Böylece düşünme biçimindeki bu farklılık, beraberinde çokluğu getirir. Dolayısıyla İlk Akıl'ın Tanrı'yı düşünmesinden İkinci Akıl, kendinin mümkün varlık olduğunu düşünmesinden ise, birinci göğün (felek) nefsi ve maddesi sudûr eder (Black, 2007: 226-227).

İkinci Akıl da ilk akla kıyasla zorunlu, özü itibarıyla da mümkün bir varlık teşkil ettiğinden, çoğalma sürecini devam ettirir. Çünkü İkinci Akıl, Tanrı'yı düşünerek Üçüncü Akıl’ın, kendi özünü düşünerek de ikinci feleğin, diğer bir ifadeyle sabit yıldızlar küresinin nefsi ve maddesinin sudûr etmesine yol açar. Böylece türeyen her akıl, önce Tanrı'yı, sonra kendini düşünerek, kendinden bir sonraki aklı ve cisimleriyle birlikte bir alt basamaktaki gök küresini meydana getirir. Mevzubahis süreç, Güneş sistemindeki gezegenlerin sayısı kadar, aşağı doğru devam eder. Ay küresinin aklı olan Faal Akıl'a gelindiğinde ise, son bulur (Reisman, 2007: 64-65). Böylece Fârâbî’nin Aristoteles'ten esinlenerek, Ay üstü âlem ve Ay altı âlem olmak üzere iki kısma ayırdığı evren modelinin Ay üstü kısmı meydana gelmiş olur. Fârâbî̀ye göre, gök katmanlarından müteşekkil Ay üstü âlemin dışında veya dış kısmında ise, yokluktan başka bir şeyin mevcudiyetinden bahsedilemez (Çüçen, 2011: 202).

Faal Akıl tarafindan yönetilen Ay altı âlemdeki bütün fiziksel, kimyasal ve biyolojik oluşlar, Faal Akıl'ın egemenliği altındadır. Ay altı âlemde de devam eden meydana geliş süreci ise, Ay üstü âlemdekinin tersine gelişir. Diğer bir ifadeyle Ay altı âlemde noksandan mükemmele doğru yükselen bir hiyerarşi söz konusudur. Bu nedenle en aşağı seviyede ilk madde yer alır (Aydınlı, 2003: 159-160). İlk maddenin üzerinde dört temel element olan ateş, su, toprak ve hava bulunur. Her biri küre şeklinde basit birer varlık olan dört unsurdan her biri sıcaklık, soğukluk, yaşlık ve kuruluktan ibaret zıt karakterli dört nitelikten ikisine sahiptir. Mevzubahis niteliklerden sıcaklık ve soğukluk aktif, yaşlık ve kuruluk ise pasif durumdadır. Söz konusu niteliklerden iki zıt nitelik birbirine karışır ve karışımın bünyesinde hangi nitelik baskın gelirse, ortaya çıkan varlık, o niteliğin özelliğini taşır. Karışım faaliyeti sonucunda hiyerarşik düzene göre sırasıyla madenler, bitkiler, hayvanlar ve en mükemmel varlık olarak kabul edilen insanlar meydana gelir (Korkut, 2012: 144).

Kâinatın meydana geliş sürecini açıklayabilmek için, Fârâbî’nin açtığı yoldan ilerlemek suretiyle, Sudûr nazariyesine yönelen İbn Sînâ, öncelikle varlıkları vâcib ve mümkün varlıklar olmak üzere iki kategoriye ayırır. Böylece Tanrı'nın varlığını ve birliğini en temel şekilde ispatlamakla kalmayan İbn Sînâ, varlığın meydana geliş sürecinin başlangıcına doğru takip edilecek sebep-sebepli zincirinin ilk halkasına Vâcibü’l Vücûd olarak nitelendirdiği Tanrı’yı yerleştirir (İbn Sînâ, 2004: 35-40). Bu bakımdan varlığı zorunlu olan ve varlığa gelmek için hiçbir sebebe muhtaç olamayan, bir başka deyişle varlık sebebi yine kendisi olan Tanrı, İbn Sînâ'nın düşünce sistemine göre sebeplerin sebebi, ilk prensip ve ilk etken olması bakımından ezelî ve ebedî olarak vardır ve her zaman var olmaya devam edecektir.

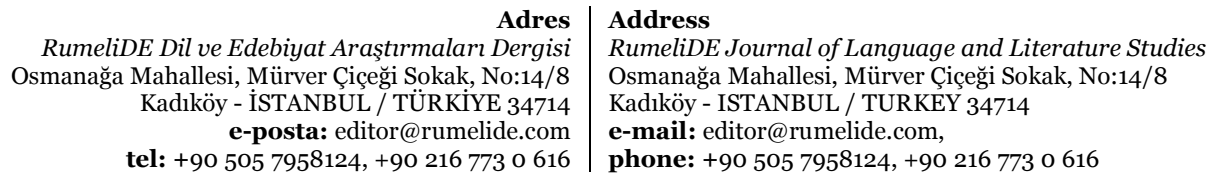

tel: +90 505 7958124, +90 2167730616 
The development of the theory of Sudûr and a new dimension given to it by Abdülhak Hâmid Tarhan through poetry / Ö. F. Karataş (pp. 423-436)

Mümkün varlıklar ise, sebep-sebepli zinciri dâhilinde meydana gelen, var olmaları zorunlu olmayan veya var olmamaları durumunda herhangi bir eksikliğe yol açmayan varlıklardır (Alper, 2014: 267268). Vâcibü’l Vücûd ile ondan türeyen mümkün varlıklar ekseninde Sudûr nazariyesine yönelen İbn Sînâ da Fârâbî'nin Aristoteles'ten esinlenerek gündeme getirdiği kozmogoniyi aynen kabul eder. Dolayısıyla İbn Sînâ'nın işaret ettiği evren modeli de yine Ay üstü âlem ile Ay altı âlemden müteşekkildir. Ay üstü âlem, Tanrı'nın kendini düşünmesi İlk Akıl'ın Tanrı'dan sudûr etmesiyle başlayıp, Faal Akıl'ın türemesiyle son bulur. Elbette aşağıya doğru sudûr eden her akıl, Tanrı'nın aksine hem kendini hem de Tanrı'yı düşünerek, yeni bir felek katmanı ve o katmanda bulunan gökcisimlerini meydana getirir (Çüçen, 2011: 206). Ay üstü âlem ile Ay altı âlem arasında âdeta bir sınır teşkil eden Faal Akıl'ın hâkimiyetindeki Ay altı âlem ise, aşağıdan yukarı doğru sırasıyla, cansız varlıklar, bitkiler, hayvanlar ve insanlardan ibaret yükselen bir varlık hiyerarşiyle meydana gelir (Özden, 2017: 106).

Kâinatın meydana gelişi mevzuunda Fârâbî ile ortak görüşler ileri süren İbn Sînâ, evrenin de Tanrı gibi ezelî olduğunu düşünerek, Fârâbî’den ayrılır. İbn Sînâ, ezelî karakterdeki Tanrı'nın ezelî olarak iradesini kullandığı kanaatindedir. Aksi takdirde, Tanrı'nın sonradan irade kazanmış olabileceği düşüncesinin ortaya çıkacağını iddia eder. Oysa Tanrı, her bakımdan mutlak olması nedeniyle, ezelî şekilde iradesini kullanmalıdır. Dolayısıyla Tanrı'nın ezelden beri irade sahibi olması gereklidir. Elbette bu düşünce, evrenin de ezelî olduğunu, sonradan yaratılmadığını kabul etmeyi gerektirir. Daha açık bir ifadeyle evrenin ezelî olması, tıpkı insan ile gölgesi arasındaki ilişki gibidir. Nasıl ki gölge kendisini meydana getiren kaynağa bağlı ve onunla eş zamanlı ise, evren de meydana geldiği kaynağa, yani Tanrı'ya bağlı olarak ezelîdir (Çüçen, 2013: 130).

Sühreverdî’nin Nûr dereceleri ile kategorize ederek, aydınlık aracılığıyla metafizik âlemi şekillendiren soyut varlıkları, aracılı̆̆ıyla da fizik âlemini şekillendiren somut varlıkları kastettiği ontolojik düşünceleri, kozmogonik düşüncelerine de kaynak teşkil eder. Topyekûn kâinatın meydana gelişini açılayabilmek için Sudûr nazariyesine yönelen Sühreverdî, bilhassa Meşşâî filozofların benimsedikleri Sudûr nazariyesini farklı bir boyuta taşır. Bu doğrultuda Meşşâi filozofların Plotinos'la aynı doğrultuda zorunlu varlık olarak Allah'tan aklın taşması sonucunda evrenin meydana geldiğini iddia etmelerine karşlık, Allah'tan Nûr'un taşması sonucunda kâinatın ortaya çıktığını ileri sürer (Sühreverdî: 2017: 96). Birden ancak bir türer prensibini merkeze alan Sühreverdî, Nûru'l Envâr (Nurların Nuru) olarak nitelendirdiği Tanrı'dan ilk olarak Nûru'l Akreb (En Yakın Nur)'in sudûr ettiğini belirtir. Sühreverdîye göre, Nûru'l Envâr'dan iki ayrı nur hâsıl olamaz. Zira iki ayrı ışı̆̆ın hâsıl olması, birbirinden ayrı nitelikte iki farklı varlığın meydana gelmesi anlamına gelir. Dolayısıyla Allah'ın da iki ayrı niteliğe sahip olmasını gerektirir ki, böyle bir durum zâtı bakımından birlik teşkil eden Allah için düşünülemez (Sühreverdî, 2012: 133).

Nûru'l Akreb, özü bakımından mümkün, ilk varlığa nispetle de vacip bir Nûr'dur. Nûru'l Envâr ile Nûru'l Akreb arasında perde (berzah) bulunmadığından, Nûru'l Akreb doğrudan Nûru'l Envâr'ı müşahede eder. Nûru'l Akreb'in zâtı, Nûru'l Envâr'daki yüceliği fark eder etmez, alaca karanlıklaşır (Sühreverdî, 2017: 98). Çünkü mükemmel düzeydeki ışık, eksik ışığı gölgede bırakır. Nûru’l Akreb, Nûru'l Envâr'dan aldığı Nûr ile soyut bir Nûr meydana getirmekle kalmayıp, kendini Nûru'l Envâr ile kıyaslaması aracılığıyla da bir gölge meydana getirir. Mevzubahis gölge, en yüce Berzah'tır. Kuşatıcı Berzah adıyla da anılan bu gölge ile Nûr, birlikten sudûr eden çokluğun başlangıç aşamasını teşkil eder (Sühreverdî, 2012: 134-136).

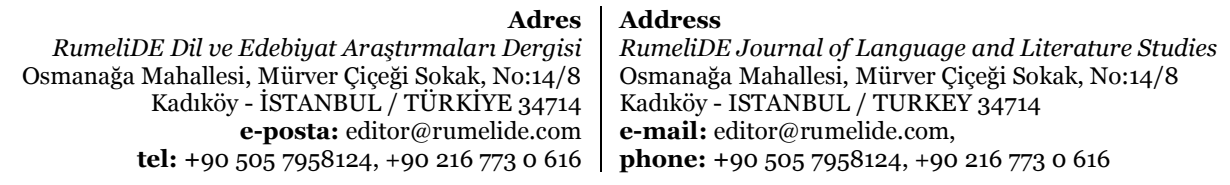

Adres
RumeliDE Dil ve Edebiyat Araşttrmaları Dergisi , Mürver Çiçeği Sokak, No:14/8 tel: +90 505 7958124, +90 2167730616 
Nûru'l Envâr'dan taşarak meydana gelen Hükümran Nûrlar, çok sayıda olmakla birlikte, sıradüzenli olarak aşağıya doğru inerler (Sühreverdî, 2012: 138-140). Dolayısıyla Nûru'l Envâr'dan Nûru'l Akreb’in türediği gibi, Nûru'l Akreb'den de İkici Nûr, İkinci Nûr'dan Üçüncü Nûr, Üçüncü Nûr'dan Dördüncü Nûr ve sırasıyla sonraki Nûrlar türemek suretiyle, sayılamayacak kadar büyük bir meblağa ulaşıncaya dek, söz konusu sudûr faaliyeti devam eder. Ancak bu noktada dikkat edilmesi gereken mevzu, Hükümran Nûrların hepsinden müstakil bir Berzah’ın (felek) türemeyeceğidir. Bu yüzden müstakil Berzahların sayısı, gezegenlerin sayısı kadar veya onlardan daha azdır (Sühreverdî, 2012: 144).

Nûru'l Envâr'ın ezelî ışımasından kaynaklanan sudûr faaliyeti, bir alt katmanda bulunan Nûr'un bir üst katmandaki Nûr'dan aldığı ışığı yansıtması ve kendini üst basamaktaki Nûr'la mukayese etmesi sonucu eksikliğini fark ederek, kendi bünyesinden daha az aydınlık bir ışık yansıtmasıyla işlerlik kazanır. Bu bakımdan bir alt katmanda, her zaman bir üst katmandakinden sayıca daha fazla yansımanın gerçekleşmesi aracılığıyla çokluk meydana gelir ve çokluk git gide artar. Diğer bir ifadeyle her yüksek Nûr, mertebece kendinden daha aşağı olan Nûrlar üzerine 1şıldarken, her aşağı mertebedeki Nûr da kendinin üstündeki ışık aracılığıyla Nûru'l Envâr'dan ışık alır. Söz konusu ışıma sayısı, yukarıdan aşağıya doğru, dikey boyutta aratarak, diğer bir ifadeyle katlanarak devam eder (Sühreverdî, 2012: 141-143).

Başlangıçta Nûru'l Envâr'ın ışığını alan Nûru'l Akreb, iki ışık yansıtır ve İkinci Hükümran Nûr meydana gelir. Böylelikle İkinci Hükümran Nûr, Nûru'l Envâr'dan hâsıl olan arazî ışıtan iki kez ışık almış olur. Çünkü bir kez doğrudan Nûru'l Envâr'dan ışık alan İkinci Hükümran Nûr, bir kez de Nûru'l Akreb'den ışık alır. Üçüncü Hükümran Nûr'un da dört kez aydınlanması söz konusudur. Zira Üçüncü Hükümran Nûr, İkinci Hükümran Nûr'dan iki, Nûru'l Akreb'den bir ve Nûru'l Envâr'dan da bir olmak üzere, dört kez ışık almak suretiyle aydınlanır. Dördüncü Hükümran Nûr ise, Üçüncü Hükümran Nûr'dan dört, İkinci Hükümran Nûr'dan iki, Nûru'l Akreb'den bir ve Nûru'l Envâr'dan da bir ışı alarak, toplamda sekiz ışık yansımasına maruz kalır. Bahsi geçen kartezyen çoğalma, son derece büyük bir miktara ulaşıncaya kadar devam eder. Bu aşamada dikkat edilmesi gereken temel husus, yukarıdan aşağıya doğru ışı̆̆ın (yansımanın) sayısal miktarı artarken, aydınlığın giderek azaldığıdır. Çünkü Nûru'l Envâr'dan uzaklaştıkça, Nûr'un parlaklığı azalır. Bir başka deyişle, Nûr'un sayısal artışı ile aydınlık derecesi ters orantılıdır (Sühreverdî, 2012: 145-146).

Sühreverdînnin kendi düşünceleriyle yeniden yorumladı̆̆ı Sudûr nazariyesinin dikey boyutta gerçekleşen tûlî tabakası, ışığın yansıma seviyesinin karanlığa dönmeye yüz tuttuğu noktada sona ermesine rağmen, sudûr faaliyeti son bulmaz. Bu aşamada sudûr, boyut değiştirerek, faaliyetine devam eder. Dolayısıyla kâinatın meydana geliş sürecini ifade eden sudûr, bu noktadan itibaren dikey boyuttan yatay boyuta evrilerek, arzî tabakayı meydana getirmek üzere faaliyet yürütmeye başlar (Sühreverdî, 2012: 148). Sudûrun arzî boyuta ulaşıncaya kadarki tûlî tabakası, maddeden bağımsız, tamamıyla Nûrlardan müteşekkil kısmıdır. Her bir üyesine genel olarak Kahir Nûr adı verilen dikey boyuttaki Nûr katmanlarının hepsi, yukarıdan aşağıya doğru, aydınlık derecelerine dayalı hiyerarşik bir düzene tabidir. Örneğin üstte bulunan katman, kendinden alttaki katman üzerinde hâkimiyet (kahr) sahibidir (Sühreverdî, 2012: 142). Altta bulunan katman da kendisine hâkim olan veya kendini aydınlatan üst katmana aşk (muhabbet) ile bağlıdır (Sühreverdî, 2012: 143). Ayrıca her bir üst katman ile alt katman arasındaki aydınlık farkı, üst katmanın zenginliğine karşın, alt katmanın muhtaçlığı veya fakirliği ile açıklanır (Sühreverdî, 2012: 141).

Sühreverdî̀ye göre, sudûrun tûlî ve arzî boyuttaki faaliyetleri birbirinden ayrı veya kopuk değil, tam aksine birbirinin devamı niteliğindeki faaliyetlerdir. Sudûrun tûlî boyuttan arzî boyuta geçeceği

\footnotetext{
Adres
RumeliDE Dil ve Edebiyat Arașttrmaları Dergisi Osmanağa Mahallesi, Mürver Ciçeği Sokak, No:14/8 Kadıköy - İSTANBUL / TÜRKIYE 34714 e-posta: editor@rumelide.com tel: +90 $5057958124,+902167730616$ 
The development of the theory of Sudûr and a new dimension given to it by Abdülhak Hâmid Tarhan through poetry / Ö. F. Karataş (pp. 423-436)

noktada, âdeta iki boyut arasındaki etkileşimi sağlamak üzere, Yatay Melekler Düzeyi’nin türediğine değinen Sühreverdî, sadece sürecin değil, aynı zamanda farklı yapılardaki iki ana katmanın da bütünlük dâhilinde oluştuğunu vurgular. Platon'un idealar âlemini anımsatan Yatay Melekler Düzeyi, maddi (somut) âlemdeki her varlığın soyut arketiplerini barındıran bir katman olarak ön plana çıkar. Dolayısıyla maddi âlemdeki her varlık, Yatay Melekler Düzeyi'ndeki kendi arketipinin melekî etkisini belirten tılsımın tesiri altındadır. Kendi arketipinin etkisi altında var olabilen her cisim, aslında kendi arketipinin bir heykeli olmaktan ibarettir. Bu nedenle Sühreverdî, söz konusu arketipleri Türlerin Erbabı (Erbâbu'l Envâ') veya Büyülerin Erbabı (Erbâbü’t Telâsim) ifadeleriyle adlandırmayı uygun bulur (Sühreverdî, 2012: 158-159). Ayrıca Erbâbu'l Envâ' düzeyinde, tûlî boyuttaki gibi varlıkların yukarıdan aşağıya doğru birbirlerini meydana getirmelerini belirten Sühreverdî, buradaki soyut varlıkların yan yana bulunduklarının altını çizer. Özetle sudûrun Erbâbu'l Envâ' katmanı, Hükümran Nûrlardan müteşekkil katmandan farklı olmakla birlikte, sabit küreler âleminin altındaki felekler, basit unsurlar ve bileşik cisimlerin yöneticileri konumundaki nurani suretlerden meydana gelmiş bir katmandır.

Sühreverdî, Sudûr nazariyesi dâhilinde metafizik âlemden fiziksel âleme doğru gerçekleşen taşma faaliyetinin son merhalesi olarak, özleri bakımından karanlıktan (maddeden) oluşan unsurlar âlemine yönelir. Dolayısıyla maddi âlemi dört temel element aracılı̆̆ıla açıklamayı uygun bulur (Sühreverdî, 2017: 56). Maddi âlemi kuran unsurlar olarak ateş, su, toprak ve havayı merkeze alan Sühreverdî, ateşi diğer üç elementin aksine, ışık kaynaklı bir unsur olarak gördüğünden, onu su, toprak ve havadan ayırır. Bir başka ifadeyle ateşi, metafizik âlemin fiziksel âlemdeki temsilcisi olarak kabul eder. Zira gerçek anlamda yeryüzünde bulunan en belirgin ışık temsilcisi ateşken, gökyüzünde bulunan en belirgin ışık temsilcisi de Güneş’tir (Sühreverdî, 2012: 178).

Sühreverdî’nin kozmogonik düşüncelerine göre, yeryüzü ve gökyüzünden ibaret fiziksel âlem; toprak, su ve havanın çeşitli oranlarda birbirlerine karışarak, farklı varlıkları meydana getirdikleri âlemdir. Söz konusu üç temel unsurun birbirine karışabilmesi ise, ışık temsilcisi ateşin yaydığı sıcaklığın tesiriyle gerçekleşir (Sühreverdî, 2017: 58). Dolayısıyla her varlık, kendi bünyesindeki baskın unsurun niteliğine göre fiziksel âlemde bir yer edinir. Böylelikle yeryüzünden gökyüzüne doğru sırasıyla toprak, su ve hava arasında hiyerarşik bir düzen meydana gelmiş durumdadır. Bahsi geçen hiyerarşik düzen, üç unsurun ışığı geçirgenlik derecelerine ve ağırlıklarına dayalıdır (Sühreverdî, 2017: 56). Söz gelimi, ışığı bünyesinden hiç geçirmeyen toprak, ağırlığının da tesiriyle, en alt kısma toplanarak, yeryüzünü şekillendirir. Işığı kısmen geçiren yarı saydam yapıdaki su, topraktan daha hafif olması nedeniyle toprağın üzerine toplanır ve buharlaşmak suretiyle, gökyüzüne doğru yükselebilir. Tamamen saydam yapıdaki hava ise, ağırlığının da etkisiyle en yükseğe çıabildiğinden gökyüzünü oluşturur. Mevzubahis hiyerarşinin her bir katmanında bulunan toprak, su ve havadan ibaret üç basit unsur, sıcaklığın etkisiyle farklı oranlarda birleşerek, bileşik yapıdaki cisimleri meydana getirir (Sühreverdî, 2012: 182184).

Bileşik yapıdaki varlıklar arasında da yetkinliklerine göre giderek yükselen bir hiyerarşi söz konusudur. Sühreverdî açısından, basit yapıdaki unsurlar çeşitli oranlarda birleşerek sırasıyla; maden, bitki, hayvan ve insanı meydana getirirler (Sühreverdî, 2012: 185). Maddi âlemdeki en mükemmel karışımın insan olduğunu belirten Sühreverdî, fiziksel âlemdeki herhangi bir varlığın meydana geliş, değişme ve yok oluş süreçlerinin de, yine üç unsur ve sıcaklık aracılığıyla gerçekleştiğine işaret eder. Sühreverdî̀ye göre, oluş ve bozuluş âlemindeki tüm vakalar ve varlıklar, feleklerin döngüsel hareketlerinin tesiriyle meydana gelir. Bahsi geçen döngüsel hareketler, hadiselerin varlığa geliş

\footnotetext{
Adres | Address

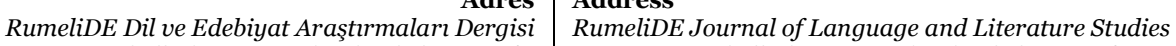
Osmanağa Mahallesi, Mürver Çiçeği Sokak, No:14/8 Osmanağa Mahallesi, Mürver Çiçeği Sokak, No:14/8 Kadıköy - İSTANBUL / TÜRKIYE 34714 Kadıköy - ISTANBUL / TURKEY 34714 e-posta: editor@rumelide.com e-mail: editor@rumelide.com, tel: +90 505 7958124, +90 2167730616 phone: +90 505 7958124, +90 2167730616
} 
illetleridir. Fakat felekler, değişimin yanı sıra, asla basit unsurların bileşiminden meydana gelmenin hükmü altına girmezler (Sühreverdî, 2012: 168).

Sühreverdî’nin Sudûr nazariyesi aracıllğııla açıklamaya çalıştığı kendi evren tasavvuruna göre kâinat, ezelî ve ebedî kabul edilmelidir. Çünkü evrenin Nûru’l Envâr'dan taşan Nûrlar aracıllğıyla oluştuğunu düşünmek, evrenin de kendinden sudûr ettiği Allah'la aynı doğrultuda ezelî olmasını gerektirir. Aksi düşünüldüğünde, Allah'n başlangıçta Nûr saçmayıp, belli bir müddet sonra Nûr saçmaya başladığı sonucu açı̆̆a çıkar (Sühreverdî, 2017: 88-89). Dolayısıyla Allah'ın sonradan Nûrlandığını düşünmek, onun hâdis (yaratılmış) olduğu ve değişime tabi olduğu sonucunu doğurur. Oysa Nûru'l Envâr, ne yaratılmıştır ne de sonradan Nûr saçma yetisini kazanmıştır. Allah zâtı itibarıyla ezelî olarak vardır ve ezelî şekilde Nûr saçmaktadır. Dolayısıyla Allah'tan yayılan Nûr aracılığıyla varlığa gelen evren de bütün unsurlarıyla ezelîdir (Sühreverdî, 2012: 165-166). Ayrıca Allah'ın ezelde parlamaya (Nûr saçmaya) başlayıp, belli bir zaman sonra söneceği de düşünülemez. Bu bakımdan Allah'ın ebediyen parlayacak olması, sudûrun da kesintisiz şekilde devam etmesine imkân sunacağından, ezelî şekilde var olan evrenin, aynı zamanda ebedî olmasını da gerektirir. Sonuç itibarıyla kâinat açısından zamanın başlangıcı ve işleyişi Allah ile eş zamanlıdır. Diğer bir ifadeyle evren ezelde meydana gelip, ebediyen varlığını sürdürecek kadim bir bütünü ifade etmektedir (Sühreverdî, 2012: 166-167).

\section{Tasavvuf felsefesinde Sudûr nazariyesi}

Bilhassa Vahdet-i Vücûd öğretisiyle tasavvuf felsefesinde ön plana çıan İbn Arabî’nin "tecelligâh" olarak nitelendirdiği kâinat, Allah'ın tecellisiyle ortaya çıkan ardışık taayyün ve tenezzül mertebelerinden ibarettir. Burada dikkat edilmesi gereken mevzu, Allah'ın tecellisinin ezelî ve ebedî olduğudur. Ayrıca tecelli mertebelerinin belli bir sıraya göre inmesi veya gerçekleşmesi, zaman bakımından öncelik ve sonralık değil, mertebe bakımından öncelik ve sonralığa dayanmasıdır (İbn Arabî, 2007: 429). Çünkü tecelli, Allah’nn zâtı gereği ezelî olarak mevcuttur. Bu bağlamda yaratılış tekerrür etmeksizin (İbnü'l Arabî, 2013: 51), her bir an itibarıyla varlıkta yokluğa ve ardından yine yokluktan varlığa doğru durmaksızın devam etmektedir. İbn Arabî’nin düşünce sistemine göre Allah, ezelî olarak Lâ-taayyün mertebesindedir. Söz konusu bu ilk mertebe, Zât ve Ahadiyet mertebesi adlarıyla da anılır. Zira bu mertebede Allah, Gayb-ı Mutlak, diğer bir ifadeyle Gaybü'l Gayb hâlindedir. İnsan açısından tam anlamıyla bir sır konumundaki bu aşamada Allah'ın adı, sadece "Ehad"dır. Onun bütün isim ve sıfatları Zât-ı Ulûhiyette yok olmuş durumdadır (Kılıç, 1999: 501).

Gizli bir hazine konumundaki Allah, bilinmeyi diler ve böylece tecelli eder. Allah'ın kendi iradesiyle tecelli etmesiyle, Taayyün-i Evvel mertebesi meydana gelir. Adı geçen bu ilk taayyün mertebesi, Allah'ın isim ve sıfatlarının ayrılmaksızın bir bütün olarak tecelli ettiği mertebedir (Kıllı̧, 1999: 502). İlk taayyünün ardından tecellinin ikinci mertebesi, diğer bir ifadeyle Taayyün-i Sânî gerçekleşir (Demirli, 2013: 356). İkinci taayyün mertebesinde Allah'ın isimleri ve sıfatları artık birbirinden ayrllarak tecelli eder. Allah, soyuttan somuta doğru tecelli ederek meydana getireceği evreni, nesneleri ve olayları yaratmadan önce, varlığa gelmiş ve gelecek her şeyi açıkça bildiğinden, varlığa gelecek bütün varlıkların soyut suretleri, onun ilminde sabittir (Kılıç, 1999: 502-503). Dolayısıyla Taayyün-i Sânî mertebesi, somut düzeyde varlık bulacak unsurların soyut suretlerini barındıran Ayân-ı Sabite mertebesi adıyla da anılır (Suad El-Hakîm, 2005: 90-94).

Ayân-ı Sabite'nin kesifleşmesi veya zahire doğru bir adım daha atmasıyla Mertebe-i Ervâh (Ruhlar Âlemi) ortaya çıar. Söz konusu kesifleşme sonucu Cevher-i Basit hâsll olur. Mertebe-i Ervâh’taki varlıklar kendilerini, kaynaklarını ve benzerlerini idrak edebilme yetisine sahip varlıklardır. Ancak

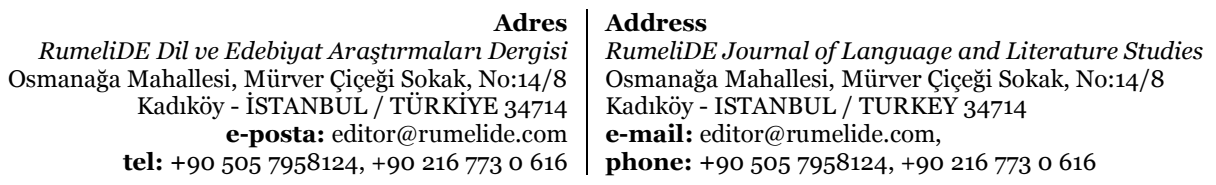


The development of the theory of Sudûr and a new dimension given to it by Abdülhak Hâmid Tarhan through poetry / Ö. F. Karataş (pp. 423-436)

bunlar, somut düzeyde veya maddi birer cisim değillerdir. Çünkü henüz madde ve maddeden müteşekkil herhangi bir terkip meydana gelmediğinden, bu mertebedeki varlıklar da duyularla algılanamayan varlıklardır (Kılıç, 1999: 503). Mertebe-i Ervâh'ın kesifleşmesiyle de Mertebe-i Misâl şekillenir. Mertebe-i Ervâh'taki basit cevherler, Misâl Âlemi'nde bileşik cevherlere dönüşürler. Dolayısıyla Misâl Âlemi'ndeki varlıklar, kendilerinden aşağıda bulunan Mertebe-i Şehâdet'e kıyasla latif, kendilerinden yukarıda yer alan Mertebe-i Ervâh'a nazaran daha kesif yapıdaki varlıklardır. Ayrıca bu âleme Misâl Âlemi denilmesinin nedeni, Mertebe-i Ervâh'taki her ferdin Cisimler Âlemi'nde bürüneceği suretlerin birer mislini barındırmasıdır (Schimmel, 2012: 287). Misâl Âlemi'nin kesifleşmesiyle ise, Mertebe-i Şehâdet meydana gelir. Bileşik yapıdaki cevher-i kesifin ortaya çıktığı bu âlem oluş, değişme ve dağılmanın görüldüğü fiziksel âlemdir. Tecelli mertebelerinin sonuncusu ise, Lâ-taayyün mertebesi haricindeki bütün mertebeleri bünyesinde toplayan ve Mertebe-i Camia adiyla da anılan Mertebe-i İnsan'dır (Kılıç, 1999: 503).

\title{
4. Abdülhak Hâmid Tarhan'ın Sudûr nazariyesine katkısı
}

Plotinos'un Tanrı'dan taşan akıl sayesinde evrenin meydana geldiğine dair düşüncesiyle ortaya çıan Sudûr nazariyesi, İslam filozoflarının yorumlarıyla değişip, gelişme imkânı bulur. Bilhassa Meşşâi filozoflar tarafından benimsenen Sudûr nazariyesi, taşma faaliyetinin istemli veya zorunlu şekilde gerçekleşip gerçekleşmediğine dair tartışmaların yanı sıra, ezelî ve ebedî olarak vuku bulup bulmadığına ilişkin düşüncelerle farklı bir kimlik kazanır. Hatta Sudûr nazariyesinde Tanrı'dan taşan unsurun Akıl değil Nûr olduğu kabul edilmeye başlanır. Daha sonra bu nazariye, tasavvuf felsefesinde Tanrı'nın tecelli etmesi şeklinde ele alınmaya başlanır (Affifi, 1974: 66-67). Sudûr nazariyesinin tasavvuf felsefesinde büründüğü yeni kimlik Ülken, 2014:143), Divan şirinin temel yapı taşlarından biri hâlini alarak, asırlar boyunca Türk edebiyatındaki varlığını sürdürür. Ardından âdeta bir gelenek boyutuyla Tanzimat sonrası Türk şiirinde de kendini göstermeyi başarır.

Yaratılış mevzuuna dair kanaat belirtme noktasında temkinli davranmayı uygun bulan Abdülhak Hâmid, önceleri tasavvufi gelenekten yararlanıp, sadece genel kabuller üzerinde durarak, çeşitli çağrışımlar yordamıyla konuya yaklaşmayı tercih eder. Bu doğrultuda, yaratılışın metafizik boyutunu inkâr etmeyen hemen herkes tarafindan kabul gören, Tanrı ve onun yoktan yaratma kuvvetine dikkat çekmekle işe başlar. Ardından çeşitli şiirlerinde "zât-ı tecell”" (Tarhan, 2013: 452), "gaybü'l gayb" (Tarhan, 2013: 305), "uluhiyyet" (Tarhan, 2013: 451), "felek" (Tarhan, 2013: 139), ve "vücûd-ı vahdet" (Tarhan, 2013: 185) gibi terimleri şiirine taşımak suretiyle, tasavvuf felsefesiyle ileri sürülen Sudûr nazariyesine doğru meyleder. Böylelikle Allah'ın zâtını merkeze alarak, bütün kâinatın Allah'ın irade ve emriyle, yine Allah'ın zâtından türediğine dikkat çekmekle yetinir.

\author{
Düşün ol zâtı kim emriyle zâtından ıyân olmuş, \\ Vücûd-ı sermedîsinden zemîn ü âsmân olmuş. \\ Düşün deryâyı, her bir katre mevc-i bî-kerân olmuş, \\ Hafâyâ-yı ilâhîdir ki yek-dil, yek-zebân olmuş. (Tarhan, 2013: 572)
}

Evrenin meydana gelişine dair düşüncelerinin bu noktaya kadarki kısmında genel kabullerden ötesine geçmeyen Abdülhak Hâmid, bu noktadan itibaren Sudûr nazariyesine yeni bir boyut kazandırması bakımından ön plana çıkar. Zira İslam filozofları tarafından Sudûr nazariyesi açıklanırken, Allah’tan taşan Akıl veya Nûr aracılığıyla evrenin meydana geldiği iddia edilmesine rağmen Abdülhak Hâmid, Allah'tan taşan unsurun aslında Akıl veya Nûr değil, Zaman olduğunu iddia eder. Bu bakımdan Allah'ın Zât veya Ahadiyet mertebesinden, bütün isim ve sıfatlarıyla zuhur ettiği ilk tecelli mertebesini,

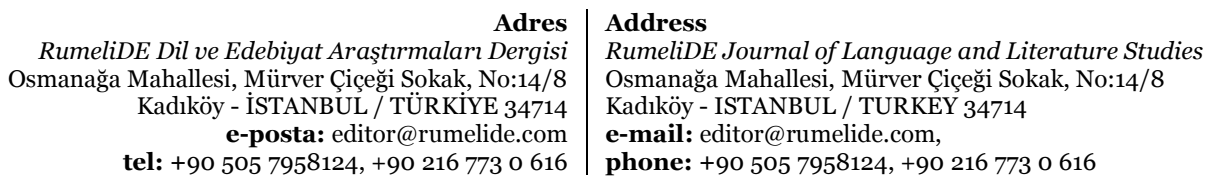


diğer bir ifadeyle Ulûhiyet mertebesini Zaman'la özdeşleştiren Abdülhak Hâmid, böylelikle sudûrun aşağıya doğru devam edecek diğer aşamalarında da Zaman unsurunun aktif rol oynadığını düşünür.

Sudûr nazariyesindeki Akıl veya Nûr'un yerine Zaman'ı yerleştiren Abdülhak Hâmid, doğrudan Zaman'ın Tanrı olduğunu ileri sürmez. Ancak Allah'ın bütün isim ve sıfatlarını karşılayan bir unsur olduğunu belirtmekten de geri durmaz. Hatta Ulûhiyet mertebesini Zaman'la özdeşleştirerek, yaratıcının namı ve yaratılışın sırrının ilk olarak Zaman unsurunda aşikâr olduğunun altını bilhassa çizer. Böylelikle Zaman unsurunun aşağı yönde taşmaya devam etmek suretiyle, kâinatın geri kalan mertebelerini veya katmanlarını meydana getireceğini düşünür (Bilgegil, 1959: 21). Dolayısıyla Abdülhak Hâmid, Allah'tan taşan Zaman'ın bütün varlıkları meydana getirmekle kalmayıp, onlara muhit teşkil ettiği, onları kapsadığı yahut kuşattığı ve onların bünyelerine yayıldığı kanaatindedir.

Bî-nihayet der, zaman, insan sana,

Çok mudur terkeylesen bir an bana?

Ey zaman, ey sâni-i rû-yi zemin,

Câmi-i âsâr-ı Rabbü'l-âlemîn!...

Sensin ancak mebde-i dehr-i kühen,

Belki tarih-i ulûhiyyet de sen!

Nâm-ı Hâlık sende kalmış yâdigâr,

Sirr-ı hilkat sende olmuş âşikâr!

Zîrde, bâlâda, bâlâ vü basît,

Cümle mevcudâta bir sensin muhît.

Hâricinde hiçbir şey yok senin,

Evvelin de, âhirin de çok senin!... (Tarhan, 2013: 451)

Kendi yaratılış teorisini desteklemek üzere, Zaman'ın niteliklerini Allah'ın nitelikleriyle karşılaştırmaya başlayan Abdülhak Hâmid, Zaman ile Allah'ın aynı niteliklere sahip olduklarına işaret eder. Söz gelimi, Zaman'ın da tıpkı Allah gibi, sonradan meydana gelmediği, diğer bir ifadeyle ezelî ve ebedî olduğu üzerinde durur. Yine Allah ile aynı doğrultuda Zaman'ın da her yerde hazır ve nazır olmasına rağmen, duyularla algılanamadığına ve mekândan münezzeh olduğuna dikkat çeker. Buna ilaveten Zaman'ın da Allah gibi, varlığa egemen olduğuna değinir. Ayrıca Zaman'ın varlı̆̆ının da Allah'ın varlı̆̆ıyla aynı şekilde mutlak ve zorunlu olduğunu ifade etmekle kalmayan şair, Zaman unsurunun da eşi ve benzeri olmadığı kanaatindedir. Böylelikle Allah'ın bütün isim ve sıfatlarını karşılama mevzuunda Zaman unsurunun herhangi bir eksiklik sergilemediğini ispat eden Abdülhak Hâmid, sudûrun Zaman unsuruyla faaliyet gösterdiğini belirtmekte herhangi bir mahzur görmez.

Eyledim tedkîk ile def-i güman,

Anladım ki sensin ancak ey zaman!...

Sende mevcuduz, senin hükmündeyiz,

Tâbi’iz her hükmüne âlemde biz!...

Bazen insan der tecelli bendedir,

Hâlbuki zât-ı tecelli sendedir!...

Bir yanın mazi ki yoktur neş'eti,

Bir yanın âti ki yoktu gâyeti!...

Sensin ancak hem kadîm ü hem cedîd,

RumeliDE Dil ve Edebiyat Araşttrmaları Dergisi Osmanağa Mahallesi, Mürver Çiçeği Sokak, No:14/8 Kadıköy - İSTANBUL / TÜRKIYE 34714 e-posta: editor@rumelide.com tel: +90 $5057958124,+902167730616$
Address

RumeliDE Journal of Language and Literature Studies Osmanağa Mahallesi, Mürver Çiçeği Sokak, No:14/8

Kadıköy - ISTANBUL / TURKEY 34714

e-mail: editor@rumelide.com,

phone: +90 505 7958124, +90 2167730616 
The development of the theory of Sudûr and a new dimension given to it by Abdülhak Hâmid Tarhan through poetry / Ö. F. Karataş (pp. 423-436)

Sensin ancak hem karîb ü hem baîd,

Mutlak u mevcud, hem gözden nihân,

Hep mekânı şâmil ü hem bî-mekân,

Bî-rakîb ü bî-şebîh ü bî-misâl,

Bî-bidâyet, bî-nihayet, bî-zevâl!...

Hükmedip dersem sana şâyândır,

Menşe'inle merci'in Rahmandır!...

Sanki Zillu-Ilahsın sen müstakil,

Arştan tâ sâfilîne müştemil!...

Sermediyyet sendedir bî-güft-gû,

Ben anı hariçte etmem cüst-cû!... (Tarhan, 2013: 452-453)

Evrenin işleyişi mevzuunda ise, pozitif bilimlerin tespit ettiği tabiat kanunlarını göz ardı etmeksizin, evrenin Allah tarafından sevk ve idare edildiğini savunan şair, bu noktada uzlaştırıcı bir tavır takınır. Evreni bir manzumeye benzeterek "takdîr-i ilâhî" ile "kanûn-ı tabiat"ı bu manzumedeki "iki mazmûn$\imath$ mürâdif” olarak ele alır. Dolayısıyla pozitif bilimlerdeki gözlem ve deneyler aracılığıyla elde edilen tabiat kanunlarının doğru, fakat sebepsiz veya tesadüfen gerçekleşmediğini, tam aksine Allah'ın takdiriyle gerçekleştiğini savunur. Bu bakımdan Allah’ın tesis ettiği düzenin işlerliğini sağlayan kanunların daha iyi anlaşılabilmesi için pozitif bilimleri zaruri görür. Diğer bir ifadeyle Allah’ın yazdığı şiirin fen bilimleriyle şerh edilmesi gerektiğini vurgular.

Tesadüfün de, derim, nâm u şânı kanundur;

Bugünkü nâmı tesadüfse neyleyim kaderin!.. (Tarhan, 2013: 190)

Takdîr-i ilâhî ile kanûn-ı tabiat;

Bunlar iki mazmûn-ı mürâdif gibi bir şey.

Birleşmede gûyâ ki tabiatla şeriat,

Ölsem de, derim ben, hükemâmız ile hem rey:

Kanûn-ı tabiat, kürenin tâliîdir o,

Ecrâm-ı semâviye de câri mi o kanûn?

Hâlık ki bu hilkat işinin sâni'idir o;

Manzume-i ekvânı meâli ile meknûn (Tarhan, 2013: 694)

Evrenin meydana gelişi, yapısı ve işleyişi mevzuunda dinlerin ileri sürdükleri Tanrı-evren ilişkisi, pozitif bilimlerle tespit edilen tabiat kanunları ve Sudûr nazariyesini şiirleri aracılığıyla bir potada eritmeyi başaran Abdülhak Hâmid, bilhassa Sudûr nazariyesine katkıda bulunmasıyla ön plana çıkar. Tıpkı bir filozof gibi, Sudûr nazariyesinin kendine ulaşıncaya kadarki serüvenine vâkıf olan şair, Zaman unsurunu merkeze alarak, nazariyeyi farklı bir boyuta taşıma gereği duyar. Akıl veya Nûr gibi unsurların Allah'a ait bütün nitelikleri eksiksiz şekilde karşlayamadıklarını düşünerek, Allah’tan taşabileceğini veya yanslyabileceğini düşündüğü daha yetkin ve Allah'ın bütün niteliklerini karşlayabilecek düzeyde farklı bir unsur arayışına girişir. Böylece mevzubahis vasıflara sahip yegâne unsurun Zaman olduğuna kanaat getirerek, Sudûr nazariyesinin merkezine Zaman'ı yerleştirmeyi uygun bulur.

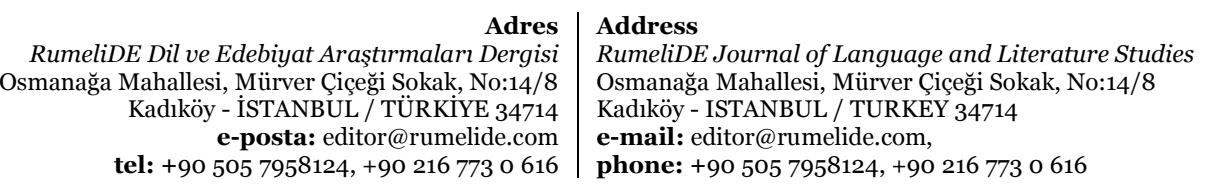




\section{Sonuç}

Platon'un idealar âlemi ile fenomenler âleminden ibaret iki ayrı âlem anlayışını âdeta bir bütün hâline getirmek üzere geliştirdiği Sudûr nazariyesiyle Plotinos, varlığın kaynağı olarak eylemde bulunmayan bir Tanrı tasarımına yönelir. Böylelikle istemsizce veya zorunlu olarak Tanrı'dan taşan Akıl'ın kesifleşerek, çeşitli katmanlar hâlinde evreni meydana getirdiğini savunur. Plotinos'un gündeme getirdiği Sudûr nazariyesi, İslam filozofları tarafından benimsenir ve kendi yaratılış teorilerini sunmak üzere istifade ettikleri bir teori hâline gelir. Öncelikle Fârâbî ve İbn Sînâ tarafından Tanrı'dan taşan unsurun Akıl olduğu kabul edilmesine rağmen, Sudûr nazariyesine belli başlı eklemelerde bulunulur. Söz gelimi, sudûr faaliyeti esnasında hangi varlık katmanlarının oluştuğu noktasında, yeni düşünceler eklenir. Ayrıca sudûrun ezelî ve ebedî olarak gerçekleşip, gerçekleşmediği tartışılır ve gitgide sudûrun ezelî ve ebedî olduğu kabul edilmeye başlanıp, bu bakımdan evrenin de ezelî ve ebedî olması gerektiği sonucuna varılır. Ayrıca sudûrun istemsizce değil, Tanrı'nın iradesiyle gerçekleştiği düşünülmeye başlanır.

Sudûr nazariyesinin temel meseleleri üzerine yeterince kafa yorulup, bu meseleler çözüme kavuşturulduktan sonra, sudûr faaliyeti esnasında Tanrı'dan taşan unsurun Akıl olup olmadığı tartışılmaya açllır. Böylelikle Sühreverdî, Tanrı'dan taşan unsurun Akıl değil, Nûr olduğunu ileri sürer. Bu görüss, İbn Arabî’nin Vahdet-i Vücûd öğretisiyle tasavvuf sahasına da intikal eder. Vahdet-i Vücûd öğretisiyle sudûra çeşitli tecelli mertebeleri eklenmekle kalmaz, Tanrı'nın aşikâr olmayı dileyip, aşkla tecelli etmesi sonucunda sudûrun gerçekleşmeye başladı̆̆ kabul edilir. Böylelikle değişip gelişen Sudûr nazariyesi, tasavvuf felsefesindeki temel yaratılış teorisi olma düzeyine yükselir. Tasavvuf, Divan şiirinin en temel yapı taşlarından biri olduğu için, Divan şiirinde de kendine yer edinen Sudûr nazariyesi, asırlar boyunca Divan şairleri tarafından Türk şiirinde kullanılır.

Divan şiirinden aldıkları bu mirası Tanzimat dönemiyle birlikte yenileştirmeye çalıştıkları şiire de yansitmaktan geri durmayan Tanzimat şairleri, bir gelenek olarak Sudûr nazariyesinden yararlanırlar. Bilhassa Tanzimat şairlerinden Abdülhak Hâmid, Sudûr nazariyesine yepyeni bir boyut kazandırır. Tanrı'dan taşan unsurun Tanrı'ya ait bütün vasıfları karşılaması gerektiğini düşünen Abdülhak Hâmid, Akıl ve Nûr'un yeterinde yetkin unsurlar olmadıklarını düşünerek, farklı bir unsur aramaya başlar. Arayışları sonucunda, Tanrı'nın bütün vasıflarını layığıyla temsil edebilecek unsurun sadece Zaman olduğuna kanaat getirir. Böylece Tanrı'dan taşan veya yansıyan unsurun Zaman olması gerektiğini ileri sürerek, Sudûr nazariyesine yeni bir bakış açısı kazandırır.

\section{Kaynakça}

Alper, Ömer Mahir (2014). “İbn Sînâ ve İbn Sînâ Okulu”. İslâm Felsefesi Tarih ve Problemler. (Ed. M. Cüneyt Kaya). İstanbul: İSAM.

Arslan, Ahmet (2012). İlkçă̆ Felsefe Tarihi V. İstanbul: İstanbul Bilgi Üniversitesi.

Aydınlı, Yaşar (2003). "Fârâbî ve Bağdat Meşşâi Okulu". İslâm Felsefesi Tarih ve Problemler. (Ed. M. Cüneyt Kaya). İstanbul: İSAM.

Bilgegil, M. Kaya (1959). Abdülhak Hâmid’in Şïrlerinde Ledünnî Mes'elelerden Allah. İstanbul: Osman Yalçın Matbaası.

Black, Deborah L. (2007). "Farabi". İslâm Felsefesi Tarihi I. (Ed. Seyyid Hüseyin Nasr-Oliver Leaman), (Çev. Şamil Öçal-Hasan Tuncay Başoğlu). İstanbul: Açlım Kitap.

Cevizci, Ahmet (2011). Felsefe Tarihi. İstanbul: Say.

Cevizci, Ahmet (2013). Paradigma Felsefe Sözlüğü. İstanbul: Paradigma.

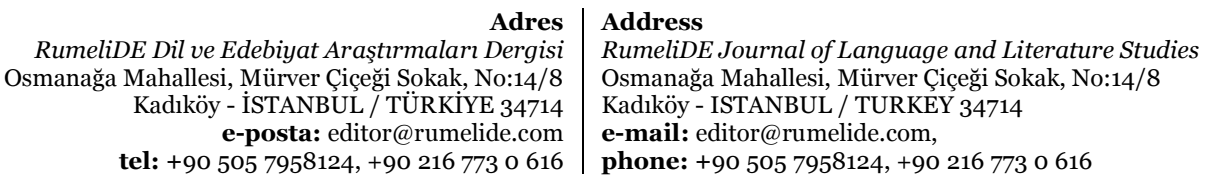


The development of the theory of Sudûr and a new dimension given to it by Abdülhak Hâmid Tarhan through poetry / Ö. F. Karataş (pp. 423-436)

Çüçen, Kadir (2013). Orta Çağ ve Rönesans’ta Felsefe. Bursa: Ezgi.

Çüçen, Kadir; Zafer, Melek Zeynep ve Esenyel, Adnan (2011). Varlık Felsefesi, Bursa: Ezgi.

Demirli, Ekrem (2013). İbnü’l Arabî Metafiziği. İstanbul: Sufi Kitap.

Ebu'l-Ala Affifi (1974). Muhyiddîn İbnu’l-Arabî’nin Tasavvuf Felsefesi. (Çev. Mehmet Dağ). Ankara: Ankara Üniversitesi İlâhiyat Fakültesi.

Fârâbî (2001). El-Medinetü'l Fâzıla. (Çev. Nafiz Danışman). Ankara: Millî Eğitim Bakanlığı.

Gökberk, Macit (2013). Felsefe Tarihi. İstanbul: Remzi.

Hançerlioğlu, Orhan (2012). Felsefe Ansiklopedisi/Kavramlar ve Akımlar VI. İstanbul: Remzi.

İbn Arabî (2007). Fütûhât-ı Mekkiyye I. (Çev. Ekrem Demirli). İstanbul: Litera.

İbn Sînâ (2004). Kitâbu'ş-Şifâ/Metafizik I. (Çev. Ekrem Demirli-Ömer Türker). İstanbul: Litera.

İbnü'l Arabî (2013). Fusûsu’l-Hikem. (Çev. Ekrem Demirli). İstanbul: Kabalcı.

Jones, William Thomas (2006). Batı Felsefesi Tarihi II. (Çev. Hakkı Hünler). İstanbul: Paradigma.

Kaya, Mahmut (2009). "Sudûr”. İslâm Ansiklopedisi. 37/467-468. İstanbul: Türkiye Diyanet Vakfı.

Kılıç, Mahmud Erol (1999). "İbnü’l-Arabî, Muhyiddin”. TDV İslâm Ansiklopedisi. 20/493-516. İstanbul: Türkiye Diyanet Vakfi.

Korkut, Şenol (2012). "Meşşâi Geleneğin Kurucu Filozofu: Fârâbî”. İslâm Felsefesi Tarihi I. (Ed. Bayram Ali Çetinkaya). Ankara: Grafiker.

Özden, H. Ömer (2017). İslâm Felsefesi Tarihi. İstanbul: Bilge Kültür-Sanat.

Plotinos (2008). Enneadlar. (Çev. Haluk Özden). İstanbul: Ruh ve Madde.

Reisman, David C. (2007). "Fârâbî ve Felsefe Müfredatı". İslam Felsefesine Giriş. (Ed. Peter AdamsonRichard C. Taylor), (Çev. M. Cüneyt Kaya). İstanbul: Küre.

Schimmel, Annemarie (2012). İslamın Mistik Boyutları. (Çev. Ergun Kocabıyık). İstanbul: Kabalcı.

Suad El-Hakîm (2005). İbnü’l Arabî Sözlüğü. (Çev. Ekrem Demirli). İstanbul: Kabalcı.

Sühreverdî (2012). Hikmetü’l İşrâk/İşrak Felsefesi. (Çev. Tahir Uluç). İstanbul: İz.

Şihâbüddîn Es-Sühreverdî (2017). El-Elvâhu'l İmâdiyye/Hikmet Levhalart. (Çev. Ahmet Kamil Cihan, Salih Yalın, Arsan Taher). İstanbul: Türkiye Yazma Eserler Kurumu Başkanlığı.

Tarhan, Abdülhak Hâmid (2013). Bütün Şiirleri. (Haz. İnci Enginün). İstanbul: Dergâh.

Ülken, Hilmi Ziya (2014). Varlık ve Oluş. Ankara: Doğu Batı.

Weber, Alfred (1998). Felsefe Tarihi. (Çev. H. Vehbi Eralp). İstanbul: Sosyal.

Zeller, Eduard (2008). Grek Felsefesi Tarihi. (Çev. Ahmet Aydoğan). İstanbul: Say.

\footnotetext{
Adres | Address

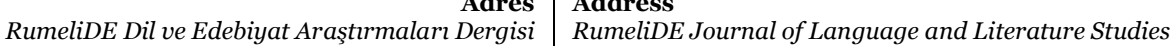
Osmanağa Mahallesi, Mürver Çiçeği Sokak, No:14/8 Osmanağa Mahallesi, Mürver Çiçeği Sokak, No:14/8 Kadıköy - ISTANBUL / TÜRKIYE 34714 Kadıköy - ISTANBUL / TURKEY 34714 e-posta: editor@rumelide.com e-mail: editor@rumelide.com tel: +90 505 7958124, +90 2167730616 phone: +90 505 7958124, +90 2167730616
} 